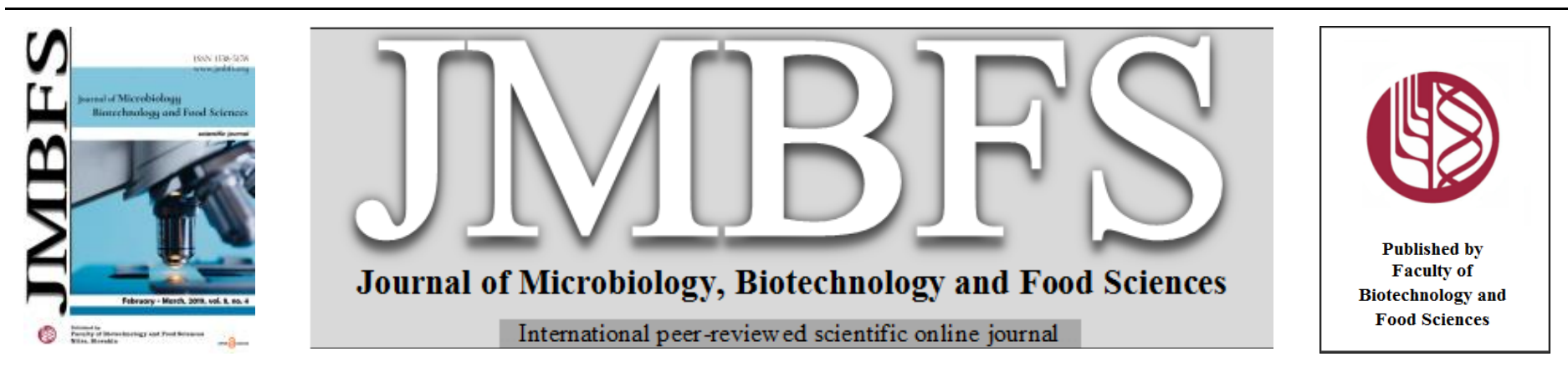

\title{
BIOLOGICAL ACTIVITY AND PRELIMINARY PHYTOCHEMICAL SCREENING OF TERMINALIA ALATA HEYNE EX ROTH
}

\author{
Sarla Saklani ${ }^{1}$, Yogita Rawat ${ }^{1}$, Sergey Plygun ${ }^{2,3}$, Mohammad Ali Shariati $^{2,3}$, Manisha Nigam ${ }^{4, *}$, Vineet Kumar Maurya ${ }^{5}$, Archana \\ Yadav $^{6}$, Abhay P. Mishra, ${ }^{1, *}$
}

\author{
$\operatorname{Address}(e s)$ : \\ ${ }^{1}$ Department of Pharmaceutical Chemistry, H. N. B. Garhwal University, Srinagar, Garhwal, 246174, Uttarakhand, India. \\ ${ }^{2}$ Researcher, Laboratory of Biocontrol and Antimicrobial Resistance, Orel State University named after I.S. Turgenev, Orel, Russia. \\ ${ }^{3}$ Researcher, All Russian Research Institute of Phytopathology, Moscow Region, Russia. \\ ${ }^{4}$ Department of Biochemistry, H. N. B. Garhwal University, Srinagar, Garhwal, 246174, Uttarakhand, India. \\ ${ }^{5}$ Department of Microbiology, H. N. B. Garhwal University, Srinagar, Garhwal, 246174, Uttarakhand, India \\ ${ }^{6}$ Department of Microbiology, Institute of Biosciences and Biotechnology, Chhatrapati Shahu Ji Maharaj (C.S.J.M.) University, Kanpur 208024, India.
}

*Corresponding author: abhaypharmachemhnbgu@gmail.com, m.nigam@hnbgu.ac.in

doi: 10.15414/jmbfs.2019.8.4.1010-1015

\section{ARTICLE INFO}

Received 1.8. 2018

Revised 11. 10. 2018

Accepted 25. 10. 2018

Published 1. 2. 2019

Regular article OPEN $\partial_{\text {ACCESS }}$

\begin{abstract}
Terminalia alata has been employed world widely in ethno-medicine including most of the Ayurvedic preparation for a treatment of ailments in Indian subcontinents. The present investigation was performed to study the in vitro antioxidant and antibacterial characteristics of hydro-alcoholic extracts of different parts (leaves, fruit, stem, and bark) of T. alata and to analyse the responsible phytochemical constituents. Phytochemical study documented the existence of carbohydrates, saponins, flavonoids, phenolics, tannins and terpenoids. Antioxidant activity was found to be highest in fruits as the lowest $\mathrm{IC}_{50}$ was observed for the same. The total phenolic content was reported to be higher in leaf extract and lower in stem extract. Whereas, among the four extracts total flavonoid content was documented to be higher in the stem extract and lower in the bark extract. The antibacterial activity of each extract was tested against three standard bacteria strains viz. Klebsiella pneumoniae, Staphylococcus aureus, and Streptococcus pneumoniae. All parts of tested plant were found to have inhibitory activity against these pathogenic bacterial species. Therefore, presence of secondary metabolites (flavonoids, terpenoids and tannins) and allied antioxidative activity, could be answerable for antibacterial activity of these extracts. There are many reports on antibacterial and other biological activity of Terminalia species other than $T$. alata, hence plants parts of $T$. alata could provide new phytochemicals showing promising antibacterial activity.
\end{abstract}

Keywords: Phytoconstituents, antioxidant, antibacterial, flavonoid, terpenoid

\section{INTRODUCTION}

In Indian subcontinent the modern system of medicine is still unavailable for certain backward places and the traditional system of medicine is still primary bases of medications to treat human ailments (Samuelson, 2004). The use of medicinal plant is now gained vital importance in rising nations of Latin America, Africa and Asia attributed to the low cost, efficacy and the fact of its accessibility and affordability for economically poor population. Due to high cost of modern drug and procedure it is not available for the economically poor population so, the treatment is totally based on medicinal plants in some backward places of India. The advent of the undesirable side effects and drug resistance of synthetic drugs, has appealed the demand of the investigation of new drug substitutes of the herbal derivation (Chandra et al., 2017). Herbs employed in traditional medications globally, are excellent source of secondary metabolites, that can be framed and manipulated for its amplest usage in modern medicines. Plant secondary metabolites are not indispensable for functioning of plants and principally formed for defense although have many other secondary roles as well e.g. tannins, flavonoids and alkaloids. Polyphenols as an essential constituent of a daily diet of humans have the ability to scavenge free radicals associated with the commencement of neurodegenerative diseases, metabolic and cardiovascular disorders (Poudel et al., 2008). Researchers are now focusing on the natural sources which have antioxidants because of the several side effects linked with the synthetic ones (Kumaran and Karunakaran, 2004).

The plant Terminalia alata belongs to the family Combretaceae which consists of approximately 530 species of trees, shrubs and lianas in 10 genera (Maarten and Christenhusz, 2016). Tree is large deciduous with black or gray acutely splintered coarse bark. It is indigenous to Thailand, Nepal, Myanmar and India, well-known in india as "Indian laurel or laurel". The geographical distribution ranges from outer Himalayas, Punjab to Sikkim, Nepal, Myanmar and Sri Lanka.
Terminalia alata is extensively found in both moist and dry deciduous forests of Southern India (Gaur, 1999). It generally attains $30-35 \mathrm{~m}$ height. Conventionally, its bark has been extensively employed in traditional system of medicines. The bark is known for its diuretic, styptic, cardiotonic properties and also useful in fractures, ulcers, diarrhea, pruritus, boils, bronchitis, fever and as a purgative (Rahman et al., 2012; Rath and Padhy, 2013). Use of fresh bark juice has been reported for the remedy of diarrhea and dysentery (Srivastava $\boldsymbol{e t}$ al., 2012; Rath and Padhy, 2012). Terminalia alata have been reported to exhibit numerous pharmacological activities like antioxidant, antifungal, anti leucorrheal and anti-hyperglycaemic (Joshi et al., 2013; Srivastava et al., 2001) The methanolic extract of its dried bark was reported to have antiviral activity against Human poliovirus-1, Herpes simplex virus-1 and Sindbis virus (Taylor $\boldsymbol{e}$ al., 1996). The activity of same extract against methicillin sensitive $S$. aureus was enhanced by UV light whereas $C$. albicans and S. cervisiae appeared to be less responsive (Taylor et al., 1996). The phytochemical constituents obtained by the trunk bark of this species are arjunic acid, arjunetin, arjunolic acid, ellagic acid and betulic acid (Mallavarapu et al., 1986).

T. alata has been known for its traditional medicinal value for the treatment and management of innumerable diseases but from the review of literature of the existing data, it is observed that considerable work has not been done yet on the comparative analysis of the various parts of $T$. alata in terms of preliminary phytochemical screening and their antioxidant, antibacterial potential. Therefore, this work was performed to assess the same. 


\section{MATERIAL AND METHODS}

\section{Reagents}

Lead acetate, Methanol, Chloroform, Acetic Anhydride, Sulphuric acid, Hydrochloric Acid, Methanol, Sodium hydroxide were procured from Sigma Chemical Co., St. Louis, MO, USA. All the other chemicals used were of analytical status.

\section{Plant Material Collection \& Hydro-alcoholic extract preparation}

The leaves, fruits, stem and bark of T. alata were collected from the nursery of Forest Research Institute, Dehradun, India. All the collected parts were washed by tap water, subsequently by distilled water to get rid of the soil debris and then dried under shade. The dried plant material was pulverised into powdered form and were extracted with Hydro-alcoholic (70:30) solution using a Soxhlet apparatus (Borosil). The solvent was dried in a rotatory evaporator (Buchi, USA) under standard conditions of temperature $\left(55^{\circ} \mathrm{C} \pm 2^{\circ} \mathrm{C}\right)$ and pressure $(40 \mathrm{mbar})$. The concentrated extract was finally lyophilized to solid residue (Labconco, USA) and then kept in a desiccator for further use.

\section{Phytochemical Screening (Preliminary Qualitative Analysis)}

The initial phytochemical analysis was performed to detect various phytochemicals in the hydro-alcoholic extract of leaves, stem, bark and fruits of T. alata using standard methods.

\section{Detection of Alkaloids}

The alkaloid content was analysed as per Raaman et al. (2006). According to which $50 \mathrm{mg}$ of extract (solvent free) was taken and mixed with few milliliter of hydrochloric acid (dilute) and filtered. Filtrate thus obtained was examined with different alkaloidal reagents as follows

\section{Mayer's test}

$5 \mathrm{ml}$ of filtrate was taken in a test tube and one or two drops of Mayer's reagent was poured slowly by the test tube's side edges. Precipitate of creamy white color signified the positive test for alkaloids.

\section{Wagner's test}

To $2 \mathrm{ml}$ filtrate added some drops of Wagner's reagent by test tube's side edges. A precipitate of reddish-brown colour confirmed that the positive test.

\section{Dragendorff's test}

In $2 \mathrm{ml}$ of filtrate, 1 to $2 \mathrm{~mL}$ of Dragendorff's reagent was poured. A prominent precipitate of yellow color indicated the positive test for alkaloid.

\section{Test for Carbohydrates}

$100 \mathrm{mg}$ of extract was solubilized in $5 \mathrm{~mL}$ of distilled water and then filtered. Filtrate was used for the following tests.

\section{Fehling's test}

$1 \mathrm{~mL}$ each of Fehling solution $\mathrm{A}$ and $\mathrm{B}$ were added to $1 \mathrm{~mL}$ of filtrate and the resulting solution was boiled on water bath. A red coloured precipitate suggested that the positive test for sugar.

\section{Benedict's test}

To $0.5 \mathrm{~mL}$ of filtrate, $0.5 \mathrm{~mL}$ Benedict's reagent was added and subsequently heated for 2 min on a water bath (boiling). A precipitate of characteristic colour suggested the presence of sugar.

\section{Detection of Saponins}

$50 \mathrm{mg}$ of extract was diluted and made up to $20 \mathrm{~mL}$ volume using distilled water Suspension was shaken for about 15 minutes in a graduated cylinder. Two centimetre foam layer hints the saponins presence.

\section{Detection of Phenolics}

\section{Lead acetate test}

$50 \mathrm{mg}$ extract was suspended in distilled water and subsequently $10 \%$ lead acetate solution $(3 \mathrm{ml})$ was mixed into it. Formation of a bulky white coloured precipitate suggests the positive test for phenolics.

\section{Detection of Tannins}

Approx. $3 \mathrm{mg}$ of plant extract dissolved in $3 \mathrm{ml}$ of methanol was diluted with chloroform and $1 \mathrm{ml}$ acetic anhydride. Eventually, sulphuric acid was poured in it. The development of green colour indicates the presence of tannins.

\section{Detection of Proteins}

The $100 \mathrm{mg}$ of extract was solubilized in distilled water $(10 \mathrm{ml})$ and filtered subsequently the filtrate was used for protein testing.

\section{Millon's test}

Some drops of Millon's reagent was mixed in $2 \mathrm{ml}$ of filtrate. Formation of a precipitate of white colour suggested the positive test for proteins.

\section{Detection of Flavonoids}

To $1 \mathrm{ml}$ of extract dissolved in methanol, added few drops of dilute $\mathrm{NaOH}$. An intense yellow colour appeared. It became colourless when a few drops of dilute acid were added to it. This confirmed the flavonoids presence.

\section{Terpenoids Detection}

$0.5 \mathrm{mg}$ of plant extract was taken in a test tube and $2 \mathrm{ml}$ of chloroform was added to it followed by $5 \mathrm{ml}$ of concentrated sulphuric acid. A reddish-brown colour at the interface indicated the positive test for terpenoids.

\section{Antioxidant activity evaluation (In vitro)}

Antioxidant profile (in vitro) of Terminalia alata was explored employing following assays:

\section{DPPH (2,2-diphenyl-1-picrylhydrazyl) radical-scavenging activity}

The free radical scavenging action of the hydro-alcoholic extracts of T. alate (Leaves, Fruit, Stem and Bark) was examined using the DPPH scavenging action by the method of Brand-Williams et al. (1995). Decline in absorbance at 517 $\mathrm{nm}$ reflected the decrement in DPPH radical. Gallic acid was employed as reference.

The scavenging capacity was estimated as follows:

DPPH Scavenging activity $(\%)=[($ Absorbance control - Absorbance sample $) /$ (Absorbance control) $] \times 100$

where; Absorbance control $=$ The absorbance of DPPH + methanol; Absorbance sample $=$ The absorbance of DPPH radical + sample/or standard .

For experimental procedure, DPPH solution having concentration of $4 \mathrm{mg} / 100 \mathrm{ml}$ was prepared in methanol. Gallic acid was employed as standard reference for determination of free radical scavenging profile of the plant extracts. Sample having $1 \mathrm{mg} / \mathrm{ml}$ concentration of either gallic acid or extracts were prepared. For determining antioxidant activity of control or test samples of extracts, total $13 \mathrm{~m}$ cocktail; containing $3 \mathrm{ml}$ of DPPH solution and mixture of gallic acid or plant extract added to methanol (total volume adjusted to $10 \mathrm{ml}$ ) was used. Cocktail containing $3 \mathrm{ml} \mathrm{DPPH}$ and $10 \mathrm{ml}$ methanol, without gallic acid or extract solution, was used as blank.

\section{Total Phenolic Content Analysis}

The total phenolic content was estimated by Folin-Ciocalteu reagent method as per Mohammad et al. (2013) with some moderations. In volumetric flask having $5 \mathrm{ml}$ distilled water, $0.5 \mathrm{ml}$ Folin-Ciocalteu's reagent and $1.5 \mathrm{ml} \mathrm{Na}_{2} \mathrm{CO}_{3}$ solution (20\%), $0.5 \mathrm{ml}$ of the sample was added. Subsequently the volume was prepared up to $10 \mathrm{ml}$ using distilled water. Following $2 \mathrm{~h}$ of incubation, absorbance was read at $765 \mathrm{~nm}$. Standard curve was plotted using gallic acid. The total phenolic content was estimated as gallic acid equals (GAE)/ g dry weight extract. Analysis was evaluated in triplicates.

\section{Total Flavonoid Content Analysis}

Flavonoid content in hydro-alcoholic extract was estimated by Aluminium chloride colorimetric assay as per Al-Owaisi et al. (2014) with few alterations Each of the extract $(0.5 \mathrm{ml}$ solution $)$ in methanol was individually mixed with 1.5 $\mathrm{ml}$ of methanol, $0.1 \mathrm{ml} 10 \%$ aluminum chloride, $0.1 \mathrm{ml} 1 \mathrm{M}$ potassium acetate, distilled water $(2.8 \mathrm{ml})$ and left at room temperature for $30 \mathrm{~min}$. The absorbance was read at $415 \mathrm{~nm}$. Total flavonoid contents were calculated from a standard curve using quercetin as reference and total flavonoid content was stated as milligrams of quercetin equals $(\mathrm{QE}) / \mathrm{g}$ of dry extract. 


\section{Determination of Total Tannin Content}

Tannin content (total) was determined by titrimetric analysis described by Atanassova and Christova-Bagdassarian. (2009). Briefly, 1.2 gm plant extract was mixed with $100 \mathrm{ml}$ distilled water for about 4 hours at room temperature subsequently the sample was filtered. $25 \mathrm{~mL}$ filtrate was poured into a conical flask of $1 \mathrm{~L}$, then $25 \mathrm{ml}$ Indigo caramine (1.2\% solution) was dissolved via heating. Subsequent to the cooling, sulphuric acid (50 $\mathrm{ml}$ of $95-97 \%)$ was mixed and solution was further diluted to $1 \mathrm{~L}$. Afterwards it was filtered and further $750 \mathrm{ml}$ of distilled water was added. $0.1 \mathrm{~N}$ potassium permanganate solution was taken for titrating till the blue colour of the solution turns into green. Few more drops were added until solution becomes golden yellow in colour. The blank test was carried out by titrating $25 \mathrm{ml}$ Indigo caramine solution mixed in $750 \mathrm{ml}$ of distilled water. Analysis was evaluated in triplicates.

\section{Calculations}

The tannins content $(\mathrm{T} \%)$ in the extract was estimated by the given formula: $T(\%)=\frac{\left(V-V_{0}\right) \times 0.004157 \times 100 \times 100}{g \times 25}$

where $V=$ Volume of the $0.1 \mathrm{~N}$ aqueous solution of potassium permanganate for titration of the sample, $\mathrm{ml}$;

$V_{0}=$ Volume of the $0.1 \mathrm{~N}$ aqueous solution of potassium permanganate for titration of the blank sample, $\mathrm{ml}$;

$0.004157=$ tannins equivalent in $1 \mathrm{ml}$ of $0.1 \mathrm{~N}$ aqueous solution of potassium permanganate $\left(\mathrm{KMnO}_{4}\right)$;

$g=$ mass of the sample taken for analysis in $\mathrm{gm}$;

\section{Determination of Antimicrobial Activity}

Comparative antibacterial activities of hydro-alcoholic extracts of different parts of T. alata were tested against three bacteria; Klebsiella pneumoniae (Gram negative rods), Staphylococcus aureus (Gram-positive cocci) and Streptococcus pneumoniae (Gram-positive cocci) using Kirby Baur Agar well diffusion assay. For antibacterial assay, each bacterium was grown in Muller-Hinton's Broth at $37^{\circ} \mathrm{C}$ and turbidity of each culture was maintained equivalent to $0.5 \mathrm{McFarland}$ standards. Each culture was inoculated to sterile Muller-Hinton's Agar (MHA) plates using sterile swab. Swab was gently rubbed on agar surface, at different angles, to achieve uniform distribution of inoculums. After inoculation, uniform wells of $5 \mathrm{~mm}$ diameter each, was cut in agar using sterile borer. Stocks of different plant parts (root, stem, leaves, fruit and bark), having concentration of 5 $\mathrm{mg} / \mathrm{ml}$ were prepared in DMSO and further dilutions were prepared from stocks. $50 \mu 1$ of each dilution was poured into wells for assaying its antibacterial efficacy against each bacterium and a single well containing pure DMSO were kept as control in each plate. Experiments were repeated thrice for confirmation of results. The plates were incubated at $37^{\circ} \mathrm{C}$ for 24 hours and 'zone of inhibitions' appeared around each well were measured with help of scale.

\section{RESULTS AND DISCUSSION}

\section{Preliminary phytochemical analysis of Terminalia alata}

The hydro-alcoholic extracts of the leaves, fruits, stem and bark of Terminalia alata employed for initial phytochemical analysis showed the existence of numerous phytochemicals as depicted in Table 1 . The results of phytochemical screening showed the presence of Carbohydrates, Saponins, Phenolic compound, Tannins, Flavonoids and Terpenoid. All the extracts gave positive test for these groups. However, Alkaloids and Proteins are absent in all the extracts tested (leaves, fruits, stem and bark).

Table 1 Screening for the Phytochemicals in the leaves, fruits, stem and bark of T. alata (Qualitative analysis).

\begin{tabular}{|c|c|c|c|c|c|}
\hline S.No. & Phytochemical Test & Leaves & Fruits & Stem & Bark \\
\hline \multirow{4}{*}{1.} & Alkaloids & & & & \\
\hline & 1) Mayer's test & - & - & - & - \\
\hline & Wagner's test & - & - & - & - \\
\hline & 3) Dragendorff's test & - & - & - & - \\
\hline \multirow{3}{*}{2.} & Carbohydrates & & & & \\
\hline & 1) Fehling's test & + & + & + & + \\
\hline & 2) Benedict's test & + & + & + & + \\
\hline 3. & Saponins & + & + & + & + \\
\hline 4. & Phenolic compounds & + & + & + & + \\
\hline 5. & Tannins & + & + & + & + \\
\hline 6. & Flavonoids & + & + & + & + \\
\hline 7. & Terpenoids & + & + & + & + \\
\hline 8. & Proteins & - & - & - & - \\
\hline
\end{tabular}

\section{Evaluation of in vitro antioxidant activity}

\section{DPPH• (2,2-diphenyl-1-picrylhydrazyl radical)-scavenging activity}

Hydro-alcoholic extracts of the leaves, fruits, stem and bark of Terminalia alata had significant DPPH radical scavenging action equated to gallic acid and this profile augmented dose dependently (Figure 1). The maximum scavenging activity for Gallic acid (as standard), Leaves, Fruit, Stem and Bark extracts were found to be $71.50 \%, 68.15 \%, 70.94 \%, 63.68 \%$ and $60.80 \%$ respectively at the concentration $5 \mathrm{mg} / 10 \mathrm{ml}$. It was documented that bark of $T$. alata had lower antioxidant activity while the fruits have higher antioxidant activity. $\mathrm{IC}_{50}$ values of each extract are shown in Figure 2. The $\mathrm{IC}_{50}$ value for standard gallic acid was observed $0.1881 \mathrm{mg} / \mathrm{ml}$. In case of plant extract (Leaves, Fruit, Stem, Bark) the $\mathrm{IC}_{50}$ value ranged from $0.1401-0.759 \mathrm{mg} / \mathrm{ml}$. The lowest $\mathrm{IC}_{50}$ value was observed for fruits $(0.1401 \mathrm{mg} / 10 \mathrm{ml})$ and the highest $\mathrm{IC}_{50}$ value was observed for bark $(0.759 \mathrm{mg} / 10 \mathrm{ml})$ while the $\mathrm{IC}_{50}$ value for leaves and stem are $(0.246 \mathrm{mg} / 10 \mathrm{ml})$ and $(0.401 \mathrm{mg} / 10 \mathrm{ml})$ respectively. According to DPPH assay, the increasing order of antioxidant potential of different $T$. alata extracts (leaf, fruit, stem and bark) was as follows: bark<stem $<$ leaf $<$ fruits. These outcomes indicate distinctive free radical scavenging action of the extract compared to gallic acid.

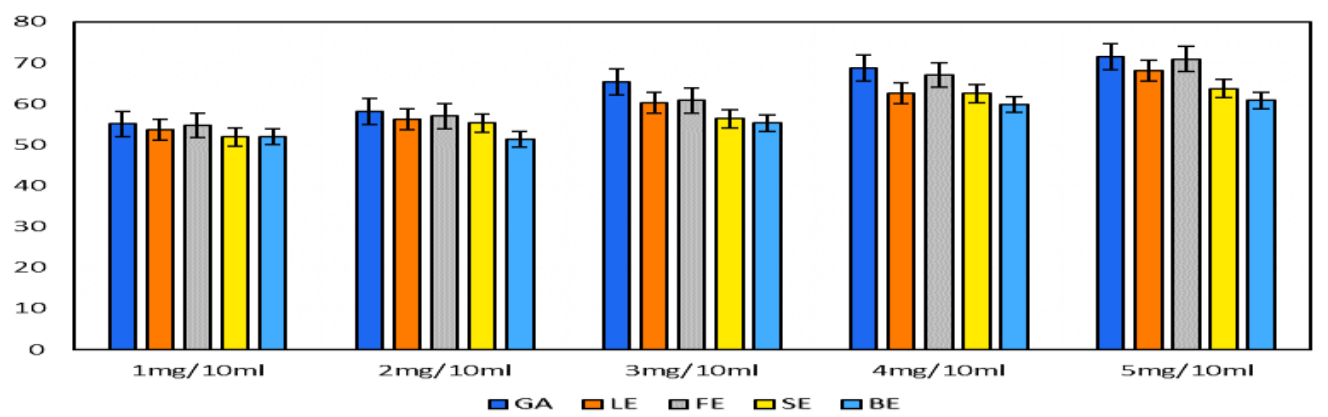

Figure 1 Anti-oxidant activity of standard gallic acid (GA), leaf (LE), fruit (FE), stem (SE) and bark (BE) extracts of T. alata. 


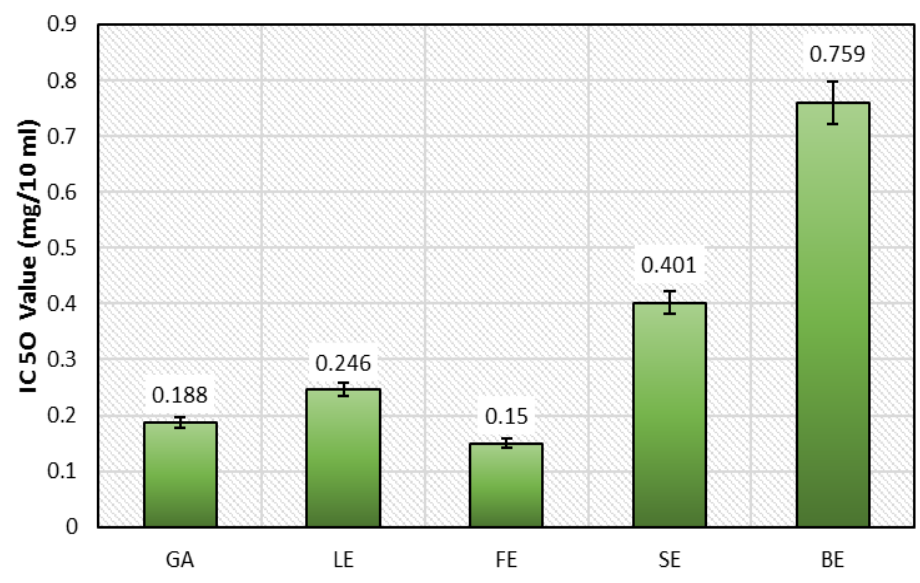

\section{Total Phenolic, flavonoid and tannin Content}

The total Phenolic content of hydro-alcoholic extracts (leaves, fruit, stem and bark) ranged from 102.56 to $120.81 \mathrm{mg} \mathrm{GAE} / \mathrm{g}$ dry extract (Table 2). In all the four extracts, leaves extract documented the greatest phenolic content $(120.81 \mathrm{mg}$ $\mathrm{GAE} / \mathrm{gm})$ whereas the stem extract displayed the least content $(102.56 \mathrm{mg}$ GAE/gm). The total Flavonoid content of hydro-alcoholic extracts (leaves, fruit, stem and bark) ranged from 80.125 to $217.625 \mathrm{mg}$ QE/g dry extract. Among the four extracts, Stem extract contained the highest $(217.625 \mathrm{mg}$ QE/gm) whereas Fruit extract had the lowest content $(80.125 \mathrm{mg}$ QE/gm). The total Tannin content of hydro-alcoholic extracts (leaves, fruit, stem and bark) were found in the range $0.48 \%-0.69 \%$. Leaves extract showed greatest Tannin content whereas bark extract depicted lowest content.

Figure $2 \mathrm{IC}_{50}$ value of standard Gallic acid (GA), Leaves (LE), Fruit (FE), Stem (SE) and Bark (BE) extracts of T. alata

Table 2 Total phenolic, flavonoid and tannin contents in Terminalia alata (leaves, fruits, stem and bark).

\begin{tabular}{lccc}
\hline Terminalia alata Extract & Total phenolic content $(\mathbf{m g ~ G A E} / \mathbf{g}$ dry extract) & Total flavonoid content $(\mathbf{m g}$ QE/g dry extract) & Total Tannin $(\%)$ \\
\hline Leaves & $120.81^{\mathrm{a}} \pm 1.2$ & $185.75^{\mathrm{a}} \pm 0.11$ & $0.69^{\mathrm{a}} \pm 0.02$ \\
\hline Fruit & $107.24^{\mathrm{b}} \pm 0.05$ & $80.125^{\mathrm{b}} \pm 0.04$ & $0.62^{\mathrm{b}} \pm 0.13$ \\
\hline Stem & $102.56^{\mathrm{c}} \pm 0.08$ & $217.63^{\mathrm{c}} \pm 0.05$ & $0.55^{\mathrm{c}} \pm 1.02$ \\
\hline Bark & $114.97^{\mathrm{d}} \pm 1.05$ & $85.13^{\mathrm{d}} \pm 0.21$ & $0.48^{\mathrm{d}} \pm 1.10$ \\
\hline
\end{tabular}

$m g Q E / g=$ milligram quercetin equivalent per gram of extract $; m g$ GAE/g = milligram gallic acid equivalent per gram of extract. Values are average of triplicates \pm standard deviation. Different Letters $(a, b$ and $c)$ within the same row are significantly different $(P<0.05)$.

\section{Antimicrobial Activity}

The antibacterial activity of different parts viz. leaf, fruit, stem and bark of $T$. alata were evaluated against three bacterial pathogens in which two strains are Gram positive bacteria and one strain was Gram negative bacteria. The antibacterial activity of different part of $T$. alata viz. Fruits, leaf, stem and bark are represented in Table 3. All the T. alata plant extracts shown antibacterial action against tested bacterial species. However, degree of antimicrobial activity varies in different parts of the plant. The higher activity was seen in fruit extract against $K$. pnemoniae (i.e. $11.2 \pm 0.21 \mathrm{~mm}$ ) at $100 \mathrm{mg} / \mathrm{ml}$ concentration followed by $S$. aureus (i.e. $10.0 \pm 0.0 \mathrm{~mm}$ ) at $100 \mathrm{mg} / \mathrm{ml}$ concentration. The leaf extract of T. alata showed least activity as compared to other parts of plant extract. The similar activity was reported in leaf and bark extract.

Table 3 Antibacterial activity of different extract of $T$. alata against pathogenic bacteria

\begin{tabular}{|c|c|c|c|c|}
\hline \multirow{2}{*}{ Plant part } & \multirow{2}{*}{ Concentration of extract used } & \multicolumn{3}{|c|}{ Zone of inhibitions appeared on MHA plates (mm) } \\
\hline & & K. pneumoniae & S. aureus & S. pneumoniae \\
\hline \multirow{4}{*}{ Leaf } & $12.5 \mathrm{mg} / \mathrm{ml}$ & $6.0 \pm 0.21$ & $7.0 \pm 0.07$ & $6.0 \pm 0.56$ \\
\hline & $25 \mathrm{mg} / \mathrm{ml}$ & $8.5 \pm 0.14$ & $8.1 \pm 0.21$ & $8.0 \pm 0.07$ \\
\hline & $50 \mathrm{mg} / \mathrm{ml}$ & $8.8 \pm 0.28$ & $9.5 \pm 0.0$ & $9.2 \pm 0.14$ \\
\hline & $100 \mathrm{mg} / \mathrm{ml}$ & $9.2 \pm 0.35$ & $9.9 \pm 0.35$ & $10.1 \pm 0.35$ \\
\hline \multirow{4}{*}{ Fruit } & $12.5 \mathrm{mg} / \mathrm{ml}$ & $7.6 \pm 0.14$ & $7.4 \pm 0.14$ & $7.9 \pm 0.28$ \\
\hline & $25 \mathrm{mg} / \mathrm{ml}$ & $6.6 \pm 0.35$ & $7.8 \pm 0.07$ & $8.0 \pm 0.21$ \\
\hline & $50 \mathrm{mg} / \mathrm{ml}$ & $7.2 \pm 0.56$ & $8.0 \pm 0.14$ & $8.2 \pm 0.21$ \\
\hline & $100 \mathrm{mg} / \mathrm{ml}$ & $11.2 \pm 0.21$ & $10.0 \pm 0.0$ & $9.5 \pm 0.14$ \\
\hline \multirow{4}{*}{ Stem } & $12.5 \mathrm{mg} / \mathrm{ml}$ & $6.0 \pm 0.28$ & $6.5 \pm 0.35$ & $7.1 \pm 0.0$ \\
\hline & $25 \mathrm{mg} / \mathrm{ml}$ & $8.2 \pm 0.14$ & $7.8 \pm 0.0$ & $8.2 \pm 0.21$ \\
\hline & $50 \mathrm{mg} / \mathrm{ml}$ & $8.9 \pm 0.21$ & $8.5 \pm 0.0$ & $8.3 \pm 0.0$ \\
\hline & $100 \mathrm{mg} / \mathrm{ml}$ & $11.0 \pm 0.28$ & $9.5 \pm 0.56$ & $9.2 \pm 0.35$ \\
\hline \multirow{4}{*}{ Bark } & $12.5 \mathrm{mg} / \mathrm{ml}$ & $7.0 \pm 0.0$ & $7.2 \pm 0.0$ & $6.3 \pm 0.07$ \\
\hline & $25 \mathrm{mg} / \mathrm{ml}$ & $8.2 \pm 0.14$ & $8.5 \pm 0.07$ & $9.2 \pm 0.0$ \\
\hline & $50 \mathrm{mg} / \mathrm{ml}$ & $9.6 \pm 0.07$ & $9.2 \pm 0.56$ & $9.5 \pm 0.56$ \\
\hline & $100 \mathrm{mg} / \mathrm{ml}$ & $9.9 \pm 0.56$ & $9.8 \pm 0.28$ & $10.5 \pm 0.56$ \\
\hline
\end{tabular}

Among different extracts, at concentration of $100 \mathrm{mg} / \mathrm{ml}$, higher activity against $K$. pneumoniae was shown by leaf and fruit extracts, followed by stem and bark, while for same concentration higher activity against $S$. aureus was shown by stem extract followed by bark, fruit and leaves. For $S$. pneumoniae at same concentration higher activity was shown by stem and bark followed by leaf and fruit extract (Figure 3-6).

Phytochemicals (both primary and secondary) possess a variety of human health effects. Genus Terminalia consist of several medicinally beneficial species that may serve as a boon to mankind, if they could be explored and researched properly. The preliminary phytochemical screening was performed on different hydro-alcoholic extracts (leaves, fruits, stem and bark) which showed the presence of carbohydrates, saponins, phenolic compound, tannins, flavonoids and terpenoids. All the extracts gave positive test for these groups. However, Alkaloids and Proteins were found to be absent in all the extracts. All these secondary plant metabolites contribute to the associated beneficial medicinal properties of plants as reported previously (Saklani et al., 2017; Nobori et al., 1994). Flavonoids reportedly display their activities via effecting permeability of membrane and by inactivating membrane-bound enzymes responsible for free radical generation for e.g. ATPase and phospholipase A2 (Hausteen, 1983). The occurrence of flavonoids in T. alata might be attributed to its antioxidant profile Moreover, competence of flavones as antioxidants is credited to several mechanisms involving metal ions chelation (iron and copper) and the free radicals scavenging property (Burda and Oleszek, 2001; Heim et al., 2002). The presence of saponins in T. alata accounts for its cytotoxic effect.

Antioxidant profile of the extract was estimated in relation to their $\mathrm{IC}_{50}$ concentration equivalent to the concentration of sample that declined the preliminary absorbance of $\mathrm{DPPH} \cdot$ to $50 \%$. The lower value of $\mathrm{IC}_{50}$ indicates higher potential to neutralize free radical. DPPH assay results indicates about the relative antioxidant profile of distinctive parts of $T$. alata.. Antioxidant analysis of $T$. alata suggests that the plant is potentially effective in terms of its antioxidant profile and contains composites that are efficient in donating hydrogen to $\mathrm{DPPH} \bullet$ so as to eliminate electrons accountable for its reactivity. The $\mathrm{DPPH} \cdot$ scavenging action of the $T$. alata fruit extract was close to that of the gallic acid used as standard, thus the study exhibited that $T$. alata fruits have effective antioxidant capacity. Interestingly, the fruits possess greates antioxidant activity than other parts of the plants. 


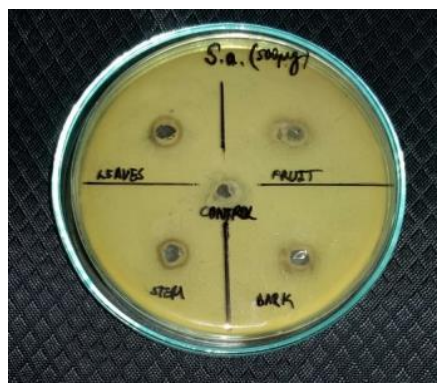

Figure 3 MHA (Muller-Hinton's Agar) plate depicting zone of inhibition against $S$. aureus at 12.5 $\mathrm{mg} / \mathrm{ml}$.

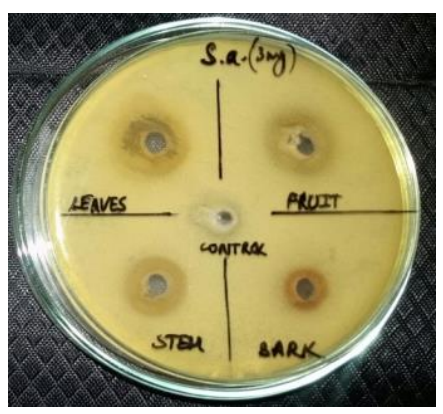

Figure 5 MHA (Muller-Hinton' Agar) plate depicting zone of inhibition against $S$. aureus at 50 $\mathrm{mg} / \mathrm{ml}$.

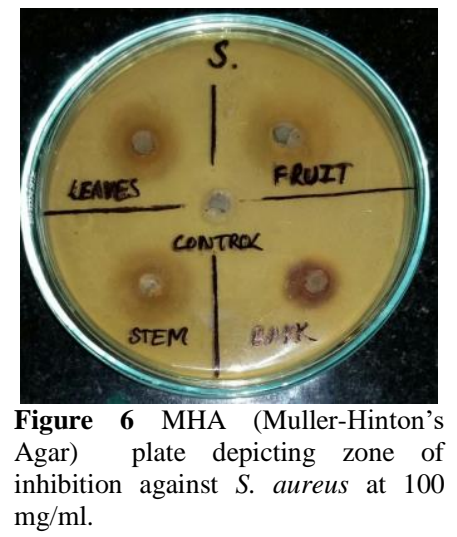

Phenolics are omnipresent plant secondary metabolites having antioxidant action and probably it is another contributing factor responsible for the activity of these extracts (Okudu et al., 1994; Tepe et al., 2006). The outcomes of this report indicated substantial level of phenolics in all parts, particularly high in leaves (Table 2).

The total flavonoids content in the different parts of $T$. alata extract was determined. Unlike the results of phenolics, the highest content was reported in stem part of the plant. Flavonoids another class of secondary plant metabolite are generally responsible to create yellow and other pigments which perform an imperative role in the plant coloration. Furthermore, Flavonoids are readily consumed by humans and they reportedly have critical anti-cancer, antiinflammatory and anti-allergic actions (Crozier and Ashihara 2006).

The Tannin content in different parts of $T$. alata showed that leaves extract had greatest total Tannin content while bark extract had lowest. Tannin is an astringent polyphenolic compound. The astringency of tannin is responsible for dry and puckery feeling in the mouth when an unripened fruit is consumed Tannins have been traditionally considered as antinutritional, so lower tannin content determines the high nutritional profile.

Findings from this study showed that the phenolics and other secondary constituents observed with the $T$. alata extracts agrees well with the subsequen results of extract's antioxidant activity. The current facts indicate that $T$. alata can efficiently scavenge ROS thus can be a possible natural antioxidant source. The antibacterial activity of leaf and bark of $T$. alata was also reported by Rath and Padhy. (2013), in which methanol extract of leaf and bark of $T$. alata showed higher activity against multiple drug resistant enteropathogenic bacteria as compared to hexane extract. Our result of antimicrobial activity was also complying with this finding. Similar finding was also reported by Taylor et al. (1996) in which they reported the significant activity against both Gram positive and Gram negative bacteria. Moreover, presence of flavonoids, terpenoids, tannins and associated antioxidant activity, could be responsible for antibacterial activity of these extracts. There are many reports on antibacterial and other biological activity of Terminalia species other than T. alata, hence plants parts of $T$. alata could provide new phytochemicals showing promising antibacterial activity.

\section{CONCLUSION}

A shift in the universal drift from synthetic to herbals has upsurge in standardization of the medicinal plant potential for their therapeutic significance. Nonetheless a major percentage of the worldwide herbal populace is still untouched that may be capable of providing securer and more effective novel medications. With this rationale, our study shows that the antioxidant and antibacterial activities of $T$. alata may be accredited to the presence of flavonoids, saponins, alkaloids, phenols and tannins in the crude extract which may be responsible for its possible therapeutic and physiological activities
Moreover, the current information suggests that $T$. alata can be a probable antioxidant of natural origin that might be of huge significance for managing radical-associated ailments. These findings support the probable efficacy of $T$. alata in treatment and prevention of ailments. Though, considering the alarming rates of increased incidences of drug-resistance further detailed researches on analysis of phytochemicals from $T$. alata and evaluation of their bioactivities is required. Further study on the separation and formulation of functiona components from the different parts of the plants should be performed to reveal its beneficial therapeutic functions.

\section{REFERENCES}

AL-OWAISI, MOOZA; AL-HADIWI, NORA, KHAN, SHAH ALAM. 2014 GC-MS analysis, determination of total phenolics, flavonoid content and free radical scavenging activities of various crude extracts of Moringa peregrine (Forssk.) Fiori leaves. Asian Pacific Journal of Tropical Biomedicine, 4 (12), 14 24. https://doi.org/10.12980/apjtb.4.201414b295.

Amarkantak region, Madhya Pradesh, India. Int J Med Arom Plant, 2, 53-59. https://doi.org/10.21275/v4i12.nov152226.

ATANASSOVA, M., CHRISTOVA-BAGDASSARIAN, C. 2009. Determination of Tannins content by Titrimetric method for comparison of different plant species. Journal of the University of the Chemical technology and Metallurgy, 44(4) 413-415. https://doi.org/10.7598/cst2016.1210

BRAND-WILLIAMS, W., CUVELIER, M.E., BERSET, C. 1995. Use of a free radical method to evaluate antioxidant activity. Lebensm Wiss Technol, 28, 2530. https://doi.org/10.1016/s0023-6438(95)80008-5.

BURDA, S., OLESZEK, W. 1983. Antioxidant and antiradical activities of flavonoids. $J$ Agric Food Chem, 49, 2774-2779. https://doi.org/10.1021/jf001413m.

CROZIER, A., ASHIHARA, H. 2006. Clifford MN. Plant Secondary Metabolites and the Human Diet. Blackwell Publishing. Oxford. Englend.

Gaur, R.D. 1999. Flora of the district Garhwal North West Himalaya". $1^{\text {st }}$ edn, Transmedia, Srinagar (Garhwal)

HEIM, K.E., TAGLIAFERRO, A.R., BOBILYA, D.J. 2002. Flavonoid antioxidants: chemistry, metabolism and structure-activity relationships. J Nutr Biochem, 13, 572-584. https://doi.org/10.1016/s0955-2863(02)00208-5.

JOSHI, A.B., BHOBE, M., BABU, A. 2013. Physicochemical and Phytochemical Investigation of Stem Bark of Terminalia tomentosa roxb (ex dc) Wight and Arn. IJAPBC, 2(3), 542-548.

KHAN, M.U., PLYGUN, S., ELMSELLEM, H., SULERIA, H.A.R. 2017. Comparative Evaluation of Polyphenol Contents and Antioxidant Activities between Ethanol Extracts of Vitex negundo and Vitex trifolia L. Leaves by Different Methods. Plants, 6, 45-55. https://doi.org/10.3390/plants6040045

KUMARAN, A., KARUNAKARAN, J. 2007. In vitro antioxidant activities of methanol extracts of five Phyllanthus species from India. LWT- Food Sci Technol, 40(2), 344-52. https://doi.org/10.1016/j.1wt.2005.09.011.

Maarten, J.M., Christenhusz, J.W. B.2016. The number of known plants species in the world and its annual increase. Phytotaxa Mangolia Press. https:// doi.org/ 10. 11646/phytotaxa.261.3.1

MALLAVARAPU, G.R, BABU, R.A.O.S, SYAMASUNDAR, K.V. 1986 Chemical Constituents of the Bark of Terminalia alata. Journal of Natural Products, 49(3), 549-50. https://doi.org/10.1021/np50045a039.

MOHAMMAD, AMZAD HOSSAIN, KHULOOD, SALIM AL-RAQMI, ZAWAN, HAMOOD AL-MIJIZY, AFAF, MOHAMMAD WELI, QASIM, AL RIYAMI. 2013. Study of total phenol, flavonoids content and phytochemical screening of various leaves crude extracts of locally grown Thymus vulgaris Asian Pac J Trop Biomed, 13, 60142-2. https://doi.org/10.1016/s2221 1691(13)60142-2

NOBORI, T., MIURAK, K., WU, D.J., TAKABAYASHIK, L.A., CARSON, D.A. 1994. Deletion of the cyclin-dependent kinase-4 inhibitor gene in multiple human cancers. Nature, 368, 753-756. https://doi.org/10.1038/368753a0

HAUSTEEN, B. 1983. Flavonoids, a class of natural products of high pharmacological potency. Biochem Pharm, 32, 1141-1148. https://doi.org/10.1016/0006-2952(83)90262-9

OKUDU, T., YOSHIDA, T., HATANO, T, 1994. Food phytochemicals for cancer prevention II. In Ho C. T, Osawa T, Huang MT, Rosen R.T. Chemistry and antioxidative effects of phenolic compounds from licorice, tea and Compositae and Labiateae herbs: 132-143. Washington, DC: American Chemical Society

POUDEL, P.R., TAMURA, H., KATAOKA, I., MOCHIOKA, I. 2008. Phenolic compounds and antioxidant activities of skin and seeds of five wild grapes and two hybrids native to Japan. J Food Comp Anal, 21(8), 622-625. https://doi.org/10.1016/j.jfca.2008.07.003

RAAMAN, N. 2006. Phytochemical technique". $1^{\text {st }}$ edn, New India Publishing Agency, New Delhi.

RAHMAN, M.A., BEGUM, K., RASHID, M.E., RASHID, M.H. 2012 Medicinal plant diversity in the flora of Bangladesh and their conservation: 2. A report on ten angiosperm families. Plant Arch, 12, 1023-1035.

RATH, S., PADHY, R.N. 2012. Surveillance of multidrug resistance of 10 enteropathogens in a teaching hospital and in vitro efficacy of 25 ethno- medicinal 
plants used by an Indian aborigine. Asian Pacif $J$ Trop Dis, 2, 336-346. https://doi.org/10.1016/s2222-1808(12)60178-9.

RATH, S., PADHY, R.N. 2013. Monitoring in vitro antibacterial efficacy of Terminalia alata Heyne ex. Roth, against MDR enteropathogenic bacteria isolated from clinical samples. Journal of Acute Medicine, 3, 93102. https://doi.org/10.1016/j.jacme.2013.06.002

RATH, S., PADHY, R.N. 2013. Monitoring in-vitro antibacterial efficacy of Terminalia alata Heyne ex Roth, against MDR enteropathogenic bacteria isolated from clinical samples. Journal of Acute Medicine, 3(3), 93-102. https://doi.org/10.1016/j.jacme.2013.06.002

SAMUELSON, G. 2004. Drugs of natural origin: A text book of pharmacognosy. Edn 5, Swedish Pharmaceutical Press, Stockholm.

SAKLANI, S., MISHRA, A.P., CHANDRA, H., ATANASSOVA, M.S. STANKOVIC, M., SATI, B., SHARIATI, M.A., NIGAM, M., SRIVASTAVA A, PATEL SP, MISHRA RK, VASISHTHA RK, SINGH A, PUSKAR AK. 2012. Ethnomedicinal importance of plants of

SRIVASTAVA, S.K., SRIVASTAVA, S. D., CHOUKSEY, B.K. 2001. New antifungal constituents from Terminalia alata. Fitoterapia, 72(2), 106-112. https://doi.org/10.1016/s0378-8741(96)01430-4.

TAYLOR, R.S.L., HUDSON, J.B., MANANDHAR, N.P. TOWERS, G.H.N. 1996. Antiviral activities of medicinal plants of southern Nepal. Journal of Ethnopharmacology, 53, 97-104. https://doi.org/10.1016/s0378-8741(96)01430-

TAYLOR, R.S.L., EDEL, F., MANANDHAR, N.P., TOWERS, G.H.N. 1996. Antimicrobial activities of southern Nepalese medicinal plants. Journal of Ethnopharmacology, 1996, 50, 97-102. $\quad$ https://doi.org/10.1016/03788741(95)01335-0

TAYLOR, R.S.L., EDEL, F., MANANDHAR, N. P., TOWER, G. H. N. 1996 Antimicrobial activities of southern Nepalese medicinal plants. Journal of Ethanopharmacology, 50(2), 97-102. $\quad$ https://doi.org/10.1016/03788741(95)01335-0.

TEPE, B., SOKMEN, M., AKPULAT, H.A., SOKMEN, A. 2006. Screening of the antioxidant potentials of six Salvia species from Turkey. Food Chem, 95, 200-204. https://doi.org/10.1016/j.foodchem.2004.12.031. 